\title{
SPIRITUALITY, GENDER, AND DRUG USE AMONG STUDENTS FROM ONE UNIVERSITY IN BARBADOS
}

\author{
Mia Amour Jules ${ }^{1}$, Samuel Noh², Hayley Hamilton³, Bruna Brands', Denise Gastaldo ${ }^{5}$, Maria da Gloria \\ Miotto Wright ${ }^{6}$, Francisco Cumsille ${ }^{7}$, Akwatu Khenti ${ }^{8}$
}

${ }^{1}$ Doctoral Student. University of the West Indies. Cave Hill. Barbados. E-mail: miajules@hotmail.com

${ }^{2}$ Ph.D. Investigator, Centre for Addiction and Mental Health, CAMH, University of Toronto. Toronto, Canada. E-mail: samuel. noh@camh.ca

${ }^{3}$ Ph.D. Investigator, CAMH, University of Toronto. Toronto, Canada. E-mail: hayley.hamilton@camh.ca

${ }^{4}$ Ph.D. Senior Scientist. Office of Research and Surveillance, Drug Strategy and Controlled Substances Programme, Health Canada and Public Health and Regulatory Policies, CAMH, University of Toronto. Toronto, Canada. E-mail: bruna.brands@camh.ca

${ }^{5}$ Ph.D. Professor in Lawrence S. Bloomberg Faculty of Nursing de la University of Toronto. Toronto, Canada. E-mail: denise. gastaldo@utoronto.ca

${ }^{6}$ Ph.D. Former Coordinator Educational Development Program Inter-American Drug Abuse Control Commission (CICAD), Secretariat for Multidimensional Security. Washington, USA. E-mail: gloriamiottowright@gmail.com

7 Ph.D. Director Interamerican Drug Observatory, CICAD, Secretariat for Multidimensional Security at Organization of American States. Washington, USA. E-mail: fcumsille@oas.org

${ }^{8}$ Doctoral Student. Director, Office of Transformative Global Health, CAMH. Toronto, Canada. E-mail: akwatu.khenti@camh.ca

\begin{abstract}
The research aimed to clarify the relationships between spirituality, gender, and drug use among undergraduate students of one university in Barbados. A quota sample of 250 students was required from the Faculty of Social Sciences as the study was part of a larger multi-centric study involving students from the Faculty of Social Sciences from seven other participating countries in Latin America and the Caribbean. Significant negative relationships were found between a student's level of spirituality and their licit and illicit drug use over the past 12 and three months. Males and females also differed significantly in terms of illicit drug use (past 12 and three months). However no gender differences were found as it related to licit drug use. Moreover, females possessed significantly higher levels of spirituality than their male counterparts. Further qualitative research should be conducted among this age group within the Barbadian context to better explain these findings.
\end{abstract}

DESCRIPTORS: Family. Spirituality. Street drugs. Students.

\section{ESPIRITUALIDADE, SEXO E USO DE DROGAS ENTRE ESTUDANTES DE UMA UNIVERSIDADE EM BARBADOS}

\begin{abstract}
RESUMO: A pesquisa teve como objetivo esclarecer as relações entre espiritualidade, sexo e uso de drogas entre estudantes de graduação de uma universidade de Barbados. Uma amostra contingente de 250 estudantes foi exigido pela Faculdade de Ciências Sociais, uma vez que o estudo fez parte de um estudo multicêntrico maior, envolvendo os alunos da Faculdade de Ciências Sociais de outros sete países participantes da América Latina e do Caribe. Foram encontradas relações negativas significativas entre o nível de um estudante de espiritualidade e de seu uso de drogas lícitas e ilícitas nos últimos 12 e três meses. Homens e mulheres também diferiram significativamente em termos de uso de drogas ilícitas (últimos 12 e três meses) . No entanto, foram encontradas diferenças de gênero, relacionadas ao uso de drogas lícitas. Além disso, as mulheres possuíam níveis significativamente mais altos de espiritualidade do que suas contrapartes masculinas. Além disso, a pesquisa qualitativa deve ser realizada entre este grupo etário no contexto de Barbados para melhor explicar esses achados. DESCRITORES: Família. Espiritualidade. Drogas ilícitas. Estudantes.
\end{abstract}

\section{ESPIRITUALIDAD, EL SEXO Y EL CONSUMO DE DROGAS ENTRE LOS ESTUDIANTES DE UNA UNIVERSIDAD EN BARBADOS}

RESUMEN: La investigación tuvo como objetivo aclarar la relación entre la espiritualidad, el sexo y el consumo de drogas entre los estudiantes de pregrado de una universidad en Barbados. Una muestra por cuotas de 250 estudiantes fue requerido por la Facultad de Ciencias Sociales como el estudio fue parte de un estudio multicéntrico grande que participen estudiantes de la Facultad de Ciencias Sociales de otros siete países participantes de América Latina y el Caribe. Relaciones negativas significativas fueron encontradas entre el nivel de un estudiante de la espiritualidad y de su uso de drogas lícitas e ilícitas en los últimos 12 y tres meses. Hombres y mujeres también difieren significativamente en términos de consumo de drogas ilícitas (últimos 12 y tres meses). Sin embargo no se encontraron diferencias de género en su relación con el uso de drogas lícitas. Por otra parte , las mujeres poseían niveles significativamente más altos de espiritualidad que sus homólogos masculinos. Además la investigación cualitativa debe llevarse a cabo dentro de este grupo de edad en el contexto de Barbados para explicar mejor estos hallazgos .

DESCRIPTORES: Familia. Espiritualidad. Drogas ilicitas. Estudiantes. 


\section{INTRODUCTION}

In Barbados and the wider Caribbean there is great concern about an apparent increase in licit and illicit drug use and its negative effects on youth and adults. Reflecting this concern, the Government of Barbados' expenditure for substance abuse services grew significantly from $\$ 26,000$ during the 2002-2003 financial year to $\$ 1.1$ million in 2009-2010. ${ }^{1}$ Drug and alcohol use remains problematic across college campuses in Barbados with the consumption of psychoactive substances often beginning in secondary school and continuing later into life. ${ }^{2}$ The early age of onset of these behaviours among Barbadian youth is particularly troubling because the college years are usually when adolescents are most likely to first experiment with alcohol and other drugs, while others are likely to move from experimentation to more frequent use. ${ }^{3-4}$ This is because many college students perceive that the use of alcohol (among other drugs) is normal acceptable behaviour. ${ }^{5}$ In the context of Barbados, early onset may mean an above-average use of drugs and alcohol in the university environment.

Despite the dominance that spiritual and religious traditions have within the region, research about the benefits of spirituality/religiousness on adolescent health has been scare to non-existent and the vast majority of international literature focuses on the role of spirituality during recovery and abstinence from licit and illicit substances. Moreover, empirical research about the effects of spirituality and religion on substance use is scarce when compared with that about the influence of other factors such as parent and peer relationships. ${ }^{6}$ This study aimed to clarify the relationship between spirituality and drug use among Barbadian youth with a specific focus on gender differences.

Integrating gender into this research was important because of its contribution to improving the understanding of differences in drug use and spirituality between men and women. The gender lens requires a researcher to recognize the impact of social and cultural constructions of masculinity and femininity and hence understand the causes of the differences and similarities demonstrated by males and females in society. ${ }^{7-8}$ Gender based findings will have implications for policy at both the university and national level. It is well known that the needs of male and females differ on campuses and hence information about these possible differences (if they exist) should be highlighted so that the specific needs of each group can be met.
The concept of spirituality can range from being closely intertwined with religion, to being something that is enhanced by religion. ${ }^{9-11}$ These conceptualisations of spirituality are likely to be applicable to the Caribbean context where a large portion of the population is affiliated with a religious denomination. The African diaspora comprises some 200 million persons in the Americas, with an estimated 23 million in the Caribbean. ${ }^{12}$ Spirituality/religiousness can develop by participating in religious activities. Moreover,beliefs and practices in the Caribbean (both formal and informal) are highly diverse ${ }^{13}$ and include, among others, Catholic, Protestant, Hindu, Muslim, Shango, Spiritual Baptist, Vudun, and Rastafari. ${ }^{13}$

Although there is no consistent definition of spirituality in the literature ${ }^{14-16}$ the term has been used synonymously with religiousness / religiosity ${ }^{17-20}$ In addition, some research also suggests that although related, spirituality can exist separately from religious beliefs and practices. ${ }^{21}$ Spirituality can generally be conceptualised as the experience of a direct relationship with a higher power, and feelings of purpose based on the belief in this power that allows for self-exploration and discovery of a meaningful life. ${ }^{22}$ As it relates to the post-secondary environment, spirituality is reappearing on college campuses, encouraging discussions about personal meaning, life's purposes, and spiritual values among students. ${ }^{11}$ One study conducted in the United States reported that $80 \%$ of incoming college students had an interest in spirituality and that nearly $50 \%$ of all incoming students reported that it was either essential or very important for colleges to encourage students' personal expression of spirituality. ${ }^{23}$ Many college students come to campus with some faith tradition and attempt to answer questions regarding their own purpose, mission, and values. ${ }^{24}$ This is likely to occur as adolescence is a time of questioning and it has been argued that failing to address spirituality ignores students' holistic development. ${ }^{25}$

The protective effects of spirituality against alcohol and drugs has been demonstrated in a study of 337 college students in the United States, using the CORE Alcohol and Drug Survey and several supplemental questions focusing on spiritual beliefs. ${ }^{26}$ The research reported that a student's spiritual beliefs had a moderate buffering effect on their decision to use alcohol and binge drink. In another study conducted to investigate the relationship between religiosity and drug use among Brazilian university students, it was found 
that religiosity was a protective factor against drug use among university students. ${ }^{27}$ Moreover, in a review of 36 studies published between 2007 and 2013, conducted to examine the relationship of religiosity and/or spirituality to substance use and abuse in adolescence; findings supported evidence of an inverse relationship between spirituality and substance use. ${ }^{28}$ The protective influence of spirituality on health damaging behaviours among adolescents may relate to the fact that most religions (upon which spiritual development can occur) include proscriptions against drug and alcohol abuse. ${ }^{29}$ Many religions specifically teach that a healthy body, mind and spirit are important. ${ }^{30}$

High levels of religiosity are associated with high levels of social bonding ${ }^{31}$ and, by extension, low levels of problem/health damaging behaviour. ${ }^{32}$ Historically, spirituality and religious traditions have enhanced the interconnectedness of persons of African descent and provided a source of strength for problem solving and self enhancement. ${ }^{33}$ Moreover, the "church" plays a definitive role as an active and caring member of society and Black churches in particular have led the promotion of healthily lifestyles as well as enhance psychological wellness among their members. ${ }^{34}$

The social constructivist perspective was the theoretical framework used to explain gender differences as it relates to drug use. An underlying principle of this approach (as it relates to gender) is that gender norms are socially constructed rather than biologically based and that these norms change across historical and cultural contexts. ${ }^{35}$ Boys and girls learn what man/woman/hood means by observing and interacting with agents of socialization such as the family, school, religious organizations, and the mass media. ${ }^{36-37}$ Gender represents the various psychological, cognitive, and behavioural differences that distinguish males from females. ${ }^{35}$ These differences are primarily the result of the process of gender role socialization. This process begins at birth whereby society dictates how males and females should behave, feel and think. ${ }^{36}$

In the current study, we argue that differences in drug use between males and females are likely to be attributed to gender socialization, specifically as it relates to risk taking. Males are more likely to engage in risk-taking behaviour compared with females from as early as three years old. ${ }^{38}$ They are also more likely to have an optimistic bias whereby they perceive their injuries to be a result of "bad luck" rather than a result of controllable behaviours. ${ }^{36}$ The development of such behavioural tendencies and cognitive biases among males may be attributed to the family environment. The family is the first agent of socialization $^{39}$ and the home environment can set the stage for future behaviours well into adolescence and young adulthood..$^{40-41}$ For example, one Canadian study conducted among mothers found that these participants responded differently to the same risky playground behaviours depending on the sex of the child. ${ }^{37}$ The mothers were also more encouraging of risk taking by sons than daughters and were slower to intervene for male children as the level of risk behaviour escalated.$^{37}$ Research has found that boys are pushed to take risks (for example when participating in competitive sports $)^{42}$ and mothers verbalized more about risk of injury to daughters and caution daughters more about injury than sons. ${ }^{37}$ These findings give some insight into how boys construct schema for what it means to be male and how masculine enactments of gender may contribute to different health risks.

Due to the nurturing that males receive from parents and peers, males are expected to take more risks $^{42}$ be independent, strong and tough, ${ }^{43}$ These traits that may contribute to health detrimental behaviours such as drug use.

A study conducted in the United States using a national and longitudinal sample of 3,680 college students reported that women are more spiritually and religiously inclined than are men. ${ }^{22}$ The researchers used the College Students' Beliefs and Values (CSBV) Survey to examine gender differences in 13 spiritual characteristics. They found that all women and men were significantly different in all 13 factors. Some of the most robust differences occurred in charitable involvement, equanimity, and religious skepticism. In the same study, when students were asked about the value that they place on "integrating spirituality into life," women were more likely than men to describe this goal as "essential." Men, however, were more inclined than women to indicate that integrating spirituality into their lives was "not important".22

In keeping with the premise that males take more risks than females it has been theorised that gender differences in religiosity are related to differences in risk preferences. ${ }^{44}$ That is, to be irreligious is to risk punishment from the divine. Additionally, the argument has also been made that the differences in gender (as it pertains to spirituality and religiosity) are a result of socially 
constructed masculine and feminine identities. For example orientation towards spirituality by women may be due to women's socialization, which stresses conflict resolution, submission, gentleness, nurturance, and other expressive values that are congruent with religious emphases. ${ }^{22}$

This study sought to investigate the relationships among spirituality, gender and drug use among Barbadian university students. The following research questions were proposed: 1) Is there a significant relationship between spirituality and drug use among university students? 2) Do female university students have significantly higher levels of spirituality than male students? 3) Are male university students more likely than female students to use licit drugs? (4) Are male university students more likely than female students to use illicit drugs?

Spirituality was defined as individual beliefs and practices related to a God or a higher power in the universe. ${ }^{10}$ Drug use was defined as the consumption of psychoactive drugs, and often, even more specifically, to illicit drugs which may or may not have medicinal value. ${ }^{45}$ Gender referred to the economic, social, and cultural attributes and opportunities associated with being male or female at a particular point in time. ${ }^{46}$ That is, it is the social/cultural interpretations imposed upon an individual based on his/her sex which can result in certain qualities and roles being attributed to and internalised by males and females.

\section{METHODOLOGY}

This study was cross-sectional in design and the survey method was used to collect data. The sample for this research consisted of undergraduate students between the ages of 18 and 24 years, attending a university in Barbados. We recruited 250 male and female students via convenience sampling from the Faculties of Social Sciences. Females comprised the majority of the sample with $58.8 \%$ being female and $41.2 \%$ male.

To protect the identities of the participants and to help with tracking the surveys, ID numbers were assigned to each questionnaire. At no time was the questionnaire ID number linked to the participant's name or any other personal information. No information that may have identified a specific participant was revealed without the participant's prior written consent. The researchers involved in the study were firmly committed to ensuring that the best interests of the research par- ticipants were maintained. We obtained informed consent obtained and guaranteed that we would provide participants with feedback on the results of the research. Ethical approval was granted on October 18 2011 from the Centre for Addiction and Mental Health Research Ethics Board and on the $7^{\text {th }}$ of November 2011 from the University of the West Indies-Cave Hill/Barbados Ministry of Health Research Ethics Committee/Institutional Review Board.

\section{The Spiritual Involvement and Beliefs Scale (SIBS)}

We used the SIBS $^{47}$ to assess the level of spirituality possessed by each student. The instrument contains 26 items measured along a 5-point Likert scale. Instrument reliability and validity are very good, with high internal consistency (Cronbach's alpha =.92); strong test-retest reliability $(\mathrm{r}=.92)$; a clear four-factor structure; and a high correlation $(r=.80)$ with another established measure of spirituality, the Spiritual Well-Being Scale.

\section{The Alcohol, Smoking, and Substance Involvement Screen Test (ASSIST)}

We used modifications of questions one and two of the ASSIST ${ }^{48}$ to measure licit and illicit drug use past 12 months and past three months. ASSIST questions relating to alcohol and tobacco were combined to form a measure of licit drug use (over the past three and past 12 months) and questions relating to cannabis, cocaine, and amphetamines were combined to form a measure of illicit drug use (over the past three and past 12 months). For a measure of drug use (past three months) research subjects responded along a 5-point Likert scale.

To investigate the relationship between spirituality and drug use a series Point-biserial correlation analyses were conducted. To determine whether there were significant differences in levels of spirituality between male and female students an independent samples t-test was conducted. Lastly a series of chi square tests of independence (with Yates Continuity Correction) were run to determine whether there were significant differences between male and female study participants related to licit and illicit drug use (past 12 and past three months. To conduct the analyses the Statistical Package for the Social Sciences (SPSS) version 19 was used. 


\section{RESULTS}

\section{Relationship between level of spirituality and licit drug use for the past $\mathbf{1 2}$ months}

We found significant weak negative correlations between level of spirituality and licit drug use for the past 12 months $(r p b=-0.224, \mathrm{~N}=250$ $\mathrm{p}<0.01$ ) and past three months $(r \mathrm{pb}=-0.265, \mathrm{~N}=250$ $\mathrm{p}<0.01$ ), and level of spirituality and illicit drug use for the past $12(r \mathrm{pb}=-0.243, \mathrm{~N}=250 \mathrm{p}<0.01)$ and three months $(r \mathrm{pb}=-0.223, \mathrm{~N}=250 \mathrm{p}<0.01)$ (Table 1). As level of spirituality increased, the likelihood of licit and illicit drugs over the past 12 and past three months decreased.

Table 1 - Point-biserial correlation analyses of level of spirituality and drug use. Barbados, 2012

\begin{tabular}{lc}
\hline Variables & $r$ pb \\
\hline $\begin{array}{l}\text { Level of spirituality and licit drug use past } 12 \\
\text { months }\end{array}$ & $-.224^{*}$ \\
$\begin{array}{l}\text { Level of spirituality and illicit drug use past } 12 \\
\text { months }\end{array}$ & $-.243^{*}$ \\
$\begin{array}{l}\text { Level of spirituality and licit drug use past three } \\
\text { months }\end{array}$ & $-.265^{*}$ \\
$\begin{array}{l}\text { Level of spirituality and illicit drug use past } \\
\text { three months }\end{array}$ & $-.223^{*}$ \\
\hline $\mathrm{n}=250 ;{ }^{*} \mathrm{p}<0.01$. &
\end{tabular}

A series of chi square tests of independence (with Yates Continuity Correction) were run to determine whether there were significant differences between male and female study participants related to licit and illicit drug use (past 12 and past three months) (Table 2). No significant association between gender and licit drug use past 12 months, $\chi^{2}(1, \mathrm{n}=250)=.299, p=.585$, phi $=-.045$ and licit drug use past three months $\chi^{2}(1, \mathrm{n}=250)=.001$, $p=.974$, phi $=-.012$. However, there was a significant association between gender and illicit drug use past 12 months $\chi^{2}(1, n=250)=13.552, p<0.001$, phi $=-.244$ and illicit drug use past three months $X^{2}(1, n=250)=12.413, \mathrm{p}<0.001$, phi $=-.234$ (Table 3).

Table 2 - Cross tabulation of gender and drug use status. Barbados, 2012

\begin{tabular}{lccccc}
\hline \multirow{2}{*}{ Drug use } & \multicolumn{2}{c}{ Gender } & \multirow{2}{*}{$\chi^{2}$} & \multirow{\Phi}{\Phi}{} \\
\cline { 2 - 3 } & Females & Males & & \\
\hline Licit drug use past 12 & months & & & \\
Never used & 31 & 18 & .299 & -.045 \\
Used & 116 & 85 & & \\
Illicit drug use past 12 months & & &
\end{tabular}

\begin{tabular}{|c|c|c|c|c|}
\hline \multirow{2}{*}{ Drug use } & \multicolumn{2}{|c|}{ Gender } & \multirow{2}{*}{$\chi^{2}$} & \multirow{2}{*}{$\Phi$} \\
\hline & Females & Males & & \\
\hline Never used & 134 & 13 & $13.552^{*}$ & -.244 \\
\hline Used & 75 & 28 & & \\
\hline \multicolumn{5}{|c|}{ Licit drug use past 3 months } \\
\hline Never used & 30 & 20 & .001 & -.012 \\
\hline Used & 117 & 83 & & \\
\hline \multicolumn{5}{|c|}{ Illicit drug use past 3 months } \\
\hline Never used & 135 & 77 & $12.413^{*}$ & -.234 \\
\hline Used & 12 & 26 & & \\
\hline
\end{tabular}

$\mathrm{n}=250 ;{ }^{*} \mathrm{p}<0.01$

As shown in table 3, females had a higher level of spirituality (mean=3.63) than males (mean=3.37). The mean difference between spirituality levels was 0.26 ; at the $95 \%$ confidence interval for the estimated population the mean difference is between 0.12 and 0.40 . The effect size was moderate $(d=0.46)$. An independent $t$-test showed that the difference between conditions was significant $(t=3.539, \mathrm{df}=248, p=.000$, two-tailed $)$.

Table 3 - Comparison of gender and spirituality scores using independent t-test analyses. Barbados, 2012

\begin{tabular}{|c|c|c|c|c|}
\hline \multirow{2}{*}{ Sample characteristics } & \multicolumn{2}{|c|}{ Gender } & \multirow{2}{*}{$t$} & \\
\hline & Female & Male & & $P$ \\
\hline Level of Spirituality & $3.63(.565)$ & $3.37(.574)$ & 3.54 & .000 \\
\hline
\end{tabular}

\section{DISCUSSION}

A significant relationship was found between a student's level of spirituality and drug use (licit and illicit) for the past 12 and three months; an increase in spirituality was associated with a decrease in drug use overall. These findings are in keeping with the literature about the direct and indirect protective influences of spirituality on health damaging behaviours. As previously mentioned, one of the main direct influences of spirituality on drug use is the fact that most religions do not condone drug and alcohol abuse and that physical health is important to consistently reaffirm one's commitment to God and to self. ${ }^{29}$ Moreover, adolescents who have developed a sense of spirituality (possibly by being a part of a religious community) are likely to have a wide network of caring peers and adults. ${ }^{29}$ Such social capital is likely to provide a much needed source of emotional support and guidance, which may dissuade health damaging behaviours such as drug use. 
We also found a significant difference between males and females in our sample related to illicit drug use. However, we found no gender differences related to licit drug use. As previously mentioned, socialization can contribute to the development of different risk taking behaviours among males and females. In some settings, masculinity has become associated with being tough, risk-taking, aggression, and having a disregard for one's body..$^{49}$ Based on gender stereotypes, an adolescent male's engagement in some risk-taking behaviour, including substance use, may be seen as a way to affirm his manhood. This may be especially true with respect to illicit substances where use can represent a disregard for one's health as well as the law. The social pressures that males encounter may also make them more vulnerable to illicit drug use. For example, girls and boys have been found to react more negatively towards male versus female peers who display behaviours or preferences that run contrary to gender stereotypes, and these reactions become increasingly negative as they grow older..$^{50}$

There was a significant difference between males and females as it related to level of spirituality whereby females possessed significantly higher levels than their male counterparts. This finding is in keeping with the literature which purports that due to the process of socialization females are taught to be nurturing, passive and submissive ${ }^{43}$ and it is possible that these are qualities make religious acceptance and commitment more likely. Being an agent of socialization it can be argued that religion lends ideological support to traditional gender roles and differential socialization. For example it has been found that religious priming can activate submissive thoughts and acceptance among some groups. ${ }^{51}$ It should be stressed again that with spirituality being related to religiosity it is likely that the religion contributes to the spiritual development of individuals in Barbados especially considering that most individuals are affiliated with a religious denomination.

\section{Limitations}

Quota sampling was used and so the findings of the study cannot be used to generalize prevalence estimates to the broader population. However, these methods are commonly used in psycho-social, epidemiological, and other healthrelated research. ${ }^{52}$ The findings of this study were intended to make inferences about the sample chosen from the university under investigation and not about the general university or wider populations.

\section{CONCLUSION AND RECOMMENDA- TIONS FOR FUTURE STUDY}

It is hoped that the findings of this study will be used to help develop or strengthen existing programmes at the university to aid in the prevention of drug use by students. Although the literature about social constructivism and risk taking does posit a general explanation for gender differences as it related to drug use and level of spirituality, it is recommended that further qualitative research be done to offer a more context specific explanation the quantitative findings of the study. This is very important considering that most research about deferential socialization has been conducted in the United States.

\section{Acknowledgements}

We would like the acknowledge the Government of Canada/DFAIT, the Organisation of America States (OAS), the Inter-American Drug Control Commission (CICAD), and the Centre for Addiction and Mental Health (CAMH) in Toronto, Canada for supporting and endorsing this project financially and technically. We would also like to thank the selected University for its invaluable support, as well as the other collaborators, advisors, and students who participated in the research.

\section{REFERENCES}

1. Plan of action for drug abusers. The Nation News. 2010 Oct 21 [access 2014 Feb 20] Available at: http:/ / www.nationnews.com/nationnews/news/18494/ plan-action-drug-abusers

2. National council on Substance (NCSA). InterAmerican Drug Abuse Control Commission (CICAD) SIDUC Secondary School Survey. Washigton (US): NCSA/CICAD; 2006.

3. Wechsler H, Kuo M. College students define binge drinking and estimate its prevalence: Results from a national survey. J Am Coll Health. 2000 Sep;49(2):5764 .

4. Fournier AK, Clarke SW. Do college students use Facebook to communicate about alcohol? An analysis of student profile pages. Cyberpsychology: J Psychosocial Res Cyberspace [online]. 2011 [access 2014 Feb 20]; 5(2):2. Available at: http:/ / cyberpsychology.eu/view. php? cisloclanku=2011121702\&article $=2$ 
5. Mallett KA, Bachrach RL, Turrisi R. Examining the unique influence of interpersonal and intrapersonal drinking perceptions on alcohol consumption among college students. J Stud Alcohol Drugs. 2009 Mar; 70(2):178-85.

6. Chitwood DD, Weiss ML, Leukefeld CG. A systematic review of recent literature on religiosity and substance use. J Drug Issues. 2008; 38(3):653-88.

7. Harris $C$. What can applying a gender lens contribute to conflict studies? A review of selected MICROCON working papers. MICROCON Research Working Paper 41, Brighton (FI): MICROCON; 2011.

8. Husu L, Hearn J, Lamsa A, Vanhala S. Leadership through the gender lens: women and men in organizations. Helsinki : Hanken School of Economics; 2010.

9. Giordan G. The body between religion and spirituality. Social Compass. 2009; 56(2):226-36.

10. Allen TM, Lo CC. Religiosity, spirituality, and substance abuse. J Drug Issues. 2010; 40(2):433-59.

11. Wood JL, Hilton AA. Spirituality and academic success: perceptions of African American males in the community college. Religion Educ. 2012; 39(1):28-47.

12. Thésée G, Carr PR. The 2011 International Year for People of African Descent (IYPAD): the paradox of colonized invisibility within the promise of mainstream visibility. Decolonization: Indigeneity, Educ Soc. 2012; 1(1):158-80.

13. Clarke C. Religion and ethnicity as differentiating factors in the social structure of the Caribbean. Oxford University (UK): MMG Working Paper; 2013.

14. Ivtzan I, Chan CP, Gardner HE, Prashar K. Linking religion and spirituality with psychological wellbeing: examining self-actualisation, meaning in life, and personal growth initiative. J Relig Health. 2013 Sep; 52(3):915-29.

15. Johnstone B, Yoon DP, Cohen D, Schopp L H, McCormack G, Campbell J, Smith M. Relationships among spirituality, religious practices, personality factors, and health for five different faith traditions. J Relig Health. 2012 Dec; 51(4):1017-41.

16. Nandram SS. Business spirituality: the inner sense of entrepreneurs. Breukelen (NL): NRI Working Paper; 2009.

17. Löckenhoff CE, Ironson GH, O'Cleirigh C, Costa PT. Five $\square$ factor model personality traits, spirituality/ religiousness, and mental health among people living With HIV. J Pers. 2009 Oct; 77(5):1411-36.

18. Johnstone B, Yoon DP, Franklin KL, Schopp $\mathrm{L}$, Hinkebein J. Re-conceptualizing the factor structure of the brief multidimensional measure of religiousness/spirituality. J Relig Health. 2009 Jun; 48(2):146-63.

19. CottonS, McGrady ME, Rosenthal SL. Measurement of religiosity/spirituality in adolescent health outcomes research: trends and recommendations. J Relig Health. 2010 Dec; 49(4):414-44.

20. Longshore D, Anglin MD, Conner BT. Are religiosity and spirituality useful constructs in drug treatment research? J Behav Health Serv Res. 2009 Apr;36(2):177-88.

21. McIntosh DN, Poulin MJ, Silver RC, Holman EA. The distinct roles of spirituality and religiosity in physical and mental health after collective trauma: a national longitudinal study of responses to the 9/11 attacks. J Behav Med. 2011 Dec; 34(6):497-507.

22. Bryant AN. Gender differences in spiritual development during the college years. Sex Roles. 2007; 56: 835-46.

23. Higher Education Research Institute. The spiritual life of college students: a national study of college students' search for meaning and purpose [online]. Los Angeles (US): University of California, Higher Education Research Institute; 2003 [access 2013 Mar 13] Available at: http://spirituality.ucla.edu/ docs/reports/Spiritual_Life_College_Students_ Full_Report.pdf

24. Brown DR, Parrish MS. College student spirituality: helping explore life's existential questions [online]; 2011 [access 2013 Mar 13]. Available at: http:/ / counselingoutfitters.com/vistas/vistas11/Article_13.pdf

25. Huitt W. A holistic view of education and schooling: Guiding students to develop capacities, acquire virtues, and provide service. Revision of paper presented at the $12^{\text {th }}$ Annual International Conference sponsored by the Athens Institute for Education and Research (ATINER). 2011 May 24-27. Athens, Greece; 2011.

26. Stewart C. The influence of spirituality on substance use of college students. J Drug Educ.2001;31(4):34351.

27. Gomes FC. Andrade AGD, Izbicki R. MoreiraAlmeida A, Oliveira LGD. Religion as a protective factor against drug use among Brazilian university students: a national survey. Rev Bras Psiquiatr. 2013 Mar;35(1):29-37.

28. Kub J, Solari-Twadell PA. Religiosity/spirituality and substance use in adolescence as related to positive development: a literature review. J Addict Nurs. 2013 Oct-Dec;24(4):247-62.

29. Bridges LJ, Moore KA. Religion and spirituality in childhood and adolescence. Washington, DC (UK): Child Trends; 2002.

30. Casey P. The psycho-social benefits of religious practise. Dublin: The Iona Institute; 2009 [access 2014 Sep 09] Available at: http:/ / www.ionainstitute.ie/ pdfs/Religious_practice.pdf

31. Idler E. The psychological and physical benefits of spiritual/religious practices Int J Nurs Stud [online]. 2007 Mar [access 2014 Sep 10]; 44(3):33948. Available at: http://spirituality.ucla.edu/docs/ newsletters/4/Idler_Final.pdf 
32. O'brien LA, Denny S, Fleming T, Clark T, Teevale T, Robinson E. The impact of religion and spirituality on the risk behaviours of young people in Aotearoa, New Zealand. Youth Stud Aust [online]. 2013[access 2014 Sep 10]; 32(4) Available at: http://journals. sfu.ca/ysa/index.php/YSA/article/view/31/191

33. Chapter 6: Substance abuse among specific population groups and settings. In: Center for Substance Abuse Treatment. Substance Abuse Treatment: addressing the specific needs of women. Treatment Improvement Protocol (TIP) Series 51. HHS Publication No. (SMA) 09-4426. Rockville (US): Substance Abuse and Mental Health Services Administration; 2009 [access 2014 Sep 12] Available at: http:/ / www. ncbi.nlm.nih.gov/books/NBK83240/

34. Boyd-Franklin N, Lockwood TW. Spirituality and religion: implications for psychotherapy with African American families. In: Walsh F, editor. Spiritual resources in family therapy. $2^{\text {nd }} \mathrm{ed}$. New York: Guilford Press; 2009. p. 141-55.

35. Ryle R. Questioning gender: a sociological exploration. $2^{\text {nd }}$ ed. Thousand Oaks (US): Sage Publications Inc; 2014.

36. Haas K. Relationship of gender to licit and illicit drug use among adolescents. Chrestomathy: Ann Rev Undergraduate Res College Charleston [online]. 2004 [access 2013 Mar 12]; 3: 92-100. Available at: http://chrestomathy.cofc.edu/documents/vol3/ haas.pdf

37. Morrongiello BA, Hogg K. Mothers' reactions to children misbehaving in ways that can lead to injury: implications for gender differences in children's risk taking and injuries. Sex Roles. 2004; 50: 103-18.

38. Morrongiello BA, Dawber T. Mothers' responses to sons and daughters engaging in injury-risk behaviors on a playground: Implications for sex differences in injury rates. J Exp Child Psychol. 2000 Jun; 76(2):89-103.

39. Ballantine JH, Roberts KA. Our social world: introduction to sociology. Thousand Oaks (US): Sage Publications Inc; 2014.

40. Ryan C, Russell ST, Huebner D, Diaz R, Sanchez J. Family acceptance in adolescence and the health of LGBT young adults. J Child Adolesc Psychiatr Nurs. 2010 Nov; 23(4):205-13.
41. Sandstrom $H$, Huerta $S$. The negative effects of instability on child development: a research synthesis. Working Families Discussion Paper 3. Washington, DC (US): Urban Institute; 2013.

42. Booth AL, Nolen PJ. Gender differences in risk behaviour: does nurture matter? Discussion paper n. 4026 Germany: IZA; 2009.

43. Brannon L. Gender: psychological perspectives. Boston (US): Allyn and Bacon; 2010.

44. Miller AS, Stark R. Gender and religiousness: can socialization explanations be saved? American J Sociology. 2002; 107(6):1399-423.

45. World Health Organization. Lexicon of alcohol and drug terms [online]; 2011 [access 2013 Mar 15]. Available at: http://www.who.int/substance_ abuse/terminology/who_lexicon/en/

46. World Health Organization. Gender, women and health: what do we mean by "sex" and "gender"? Geneva (CH): WHO; 2014.

47. Hatch RL, Burg MA, Naberhaus DS, Hellmich LK. The Spiritual Involvement and Beliefs Scale: development and testing of a new instrument. J Fam Pract. 1998 Jun; 46(6):476-86.

48. World Health Organisation. The Alcohol, Smoking and Substance Involvement Screening Test (ASSIST) Manual for use in primary care Geneva $(\mathrm{CH})$ : $\mathrm{WHO}$; 2010.

49. World Health Organization. Engaging men and boys in changing gender-based inequity in health: evidence from programme interventions [online]. Geneva (CH): WHO; 2007. [access 2013 Mar 12] Available at: https:// extranet.who.int/iris/restricted/ bitstream/10665/43679/1/9789241595490_eng.pdf

50. Courtenay WH. Constructions of masculinity and their influence on men's well-being: a theory of gender and health. Soc Sci Med. 2000 May; 50(10):1385-401.

51. Saroglou V, Corneille O, Van Cappellen P. Speak, Lord, your servant is listening: Religious priming activates submissive thoughts and behaviours. Internat J Psychol Religion. 2009; 19, 143-54.

52. Rothman KJ, Greenland S, LashTL. Modern epidemiology. $3^{\text {rd }}$ Ed. Philadelphia (US): Lippincott, Williams \& Wilkins; 2008. 